\title{
GAMBARAN CARA PENGGUNAAN ANTIBIOTIK PADA PASIEN PUSKESMAS PEMBANTU DESA BASAWANG KECAMATAN TELUK SAMPIT ${ }^{1}$ Nurul Chusna, Yurnida Harum
}

\author{
1Dosen Pengajar Program Studi D-III Farmasi, Fakultas IImu Kesehatan, \\ Universitas Muhammadiyah Palangkaraya \\ e-mail : nurulchusnaa@yahoo.com
}

\begin{abstract}
ABSTRAK
Penyakit infeksi menjadi pembunuh terbesar di dunia anak-anak dan dewasa muda. Infeksi mencapai lebih dari 13 juta kematian per tahun di Negara berkembang. Penyakit infeksi di indonesia masih termasuk dalam sepuluh penyakit terbanyak. Obat antiinfeksi adalah antimikroba antara lain antibakteri/antibiotik, antijamur, antivirus, dan antiprotozoa. Penggunaan antibiotik yang tepat sesuai dengan yang diresepkan akan memebrikan efek terapi yang diinginkan. Namun sekarang ini antibiotik telah digunakan secara bebas tanpa mengetahui dampaknya. Sarana kesehatan di puskesmas pembantu dan posyandu yang terdapat di Desa Basawang tersebut masih kurang memadai dalam hal pelayananan kesehatan terhadap masyarakat daerah tersebut yang akan mengakibatkan kurangnya pengetahuan dan kesadaran masyarakat tentang antibiotik khususnya cara penggunaan anatibiotik yang benar dan tepat inilah yang menjadi salah satu faktor terjadinya resistensi terhadap antibiotik. Menurut Peraturan Menteri Kesehatan Republik Indonesia Nomor 2406/Menkes/Per/XII/2011 resistensi adalah kemampuan bakteri untuk menetralisir dan melemahkan daya kerja antibiotika.

Dari data diatas maka dilakukan penelitian untuk mengetahui bagaimana gambaran cara penggunaan antibiotik pada pasien yang berobat ke puskesmas pembantu di desa basawang kecamatan Teluk sampit.

Penelitian ini merupakan penelitian kualitatif dengan metode deskriptif yaitu penelitian yang diarahkan untuk mendeskripsikan atau menguraikan suatu keadaan di dalam suatu komunitas atau masyarakat (Notoatmodjo, 2010). Teknik sampling yang digunakan adalah purposive sampling dan populasi dalam penelitian ini adalah pasien yang berobat ke puskesmas pembantu desa basawang, sampel dalam penelitian ini diambil berdasarkan kriteria yang telah ditentukan oleh peneliti yaitu sebanyak 10 partisipan yang mendapat pengobatan dengan antibiotik. Instrument dalam penelitian ini adalah peneliti itu sendiri. Analisis data yang dilakukan dalam penelitian ini terbagi menjadi tiga tahap yaitu reduksi data, penyajian data, dan penarikan kesimpulan / ferivikasi.

Hasil penelitian yang diperoleh dapat ditarik kesimpulan bahwa cara penggunaan antibiotik pada pasien yang berobat kepuskesmas pembantu desa basawang kecamatan teluk sampit untuk aturan pakai dan waktu penggunaan antibiotik sudah sesuai dengan yang diberikan oleh tenaga kesehatan di puskesmas pembantu Desa Basawang.
\end{abstract}

Kata Kunci: Cara Penggunaan Antibiotik, Puskesmas Pembantu

\section{PENDAHULUAN}

Pemakaian antibiotik pada saat ini

masih sangat tinggi karena penyakit infeksi

masih mendominasi. Penyakit infeksi menjadi

pembunuh terbesar di dunia anak-anak dan dewasa muda. Infeksi mencapai lebih dari 13 juta kematian per tahun di negara berkembang. Penyakit infeksi di Indonesia masih termasuk dalam sepuluh penyakit terbanyak (Hasnal et al., 2015) 
Antibiotik adalah obat yang digunakan untuk mengobati infeksi akibat bakteri, dengan cara membunuh mikroorganisme, menghentikan reproduksi bakteri, dan juga membantu system pertahanan alami tubuh untuk mengeliminasi bakteri tersebut (Nita et al., 2014). Penggunaan antibiotik akan menguntungkan dan memberikan efek bila diresepkan dan dikonsumsi sesuai dengan aturan. Namun, sekarang ini antibiotik telah digunakan secara bebas dan luas oleh masyarakat tanpa mengetahui dampak dari pemakaian yang tidak sesuai dengan aturan pakai. Penggunaan tanpa aturan pakai mengakibatkan keefektifan dari antibiotik akan berkurang. Pada penyakit infeksi tentunya di perlukan antibiotik sebagai pengobatan (Hansal et al., 2015).

Antibiotik hanya bekerja untuk mengobati infeksi yang disebabkan oleh bakteri. Penggunaan antibiotika secara rasional adalah penggunaan antibiotika yang tepat indikasi, tepat dosis, tepat pasien, tepat obat, dan waspada akan efek samping (Zakia, 2013).

Desa baswang merupakan desa yang terletak di daerah kecamatan teluk sampit. desa basawang memiliki pustu ( puskesmas pembantu) dan posyandu yang terdapat di RT 06. Berdasarkan observasi, sarana kesehatan seperti pustu dan posyandu tersebut masih kurang memadai dalam hal pelayanan kesehatan terhadap masyarakat daerah tersebut yang akan mengakibatkan kurangnya pengetahuan dan kesadran masyarakat tentang natibiotik khususnya cara penggunaan antibiotik yang benar dan tepat, serta cara penggunaan antibiotik yang tidak sesuai aturan pakai inilah yang menjadi salah satu faktor terjadinya resistensi terhadap antibiotik. Penggunaan antibiotik yang tertinggi tahun 2015 yaitu amoxicillin sebesar 2.500 kaplet, hal ini menandakan bahawa penggunaan antibiotik cukup tinggi dikalangan masyarakat desa basawang yang berobat ke pustu.

\section{METODE PENELITIAN}

Penelitian ini merupakan penelitian kualitatif dengan metode deskriptif. Metode penelitian deskriptif adalah penelitian yang diarahkan untuk mendeskripsikan atau menguraikan suatu keadaan di dalam suatu kominitas atau masyarakat (Notoatmojo, 2010). Penelitian ini dimaksudkan untuk mendapatkan gambaran cara penggunaan antibiotik pada pasien yang berobat di Pustu Desa Basawang yang mendapatkan pengobatan dengan antibiotik. Subyek penelitian yang digunakan pada penelitian ini adalah pesien yang berobat ke puskesmas pembantu desa basawang yang mendapatkan antibiotik oral. Karena jenis penelitian kualitatif sehingga tidak ada generalisasi dimana subyek penelitian tersebut diambil dan jumlah subyek 
penelitian tidak ditentukan seperti pada penelitian kuantitatif, sehingga peneliti menentukan sendiri jumlah subyek penelitiannya. Dalam penelitian ini, peneliti menargetkan jumlah subyek penlitian ini sebanyak 10 partisipan sebagai subyek penelitian.

Teknik pengambilan sampel pada penelitian ini adalah purposive sampling. Teknik ini didasarkan pada suatu pertimbangan tertentu yang dibuat oleh peneliti sendiri, berdasarkan cirri atau sifatsifat populasi yang sudah diketahui sebelumnya (Notoatmodjo, 2010). Subyek penelitian yakni partisipan yang diambil dalam penelitian ini adalah pasien yang berobat di puskesmas pembantu desa bawasang yang mendapat obat Antibiotik oral, dan bersedia untuk dikunjungi ke rumah partisipan serta bersedia untuk diwawancarai secara mendalam oleh peneliti.

\section{HASIL DAN PEMBAHASAN}

Pada penelitian ini menggunakan 10 pasien yang akan menjadi subyek, yaitu pasien yang berobat di pustu dan mendapat obat antibiotik. Dalam penelitian ini bertujuan untuk memperoleh gambaran yang mendalam dari 10 pasien yang menjadi partisipan tentang bagaimana cara penggunaan antibiotik yang dilakukan oleh 10 pasien tersebut.
Untuk mendapatkan pemahaman yang lebih luas dan mendalam terhadap situai sosial yang diteliti, maka teknik pengumpulan data bersifat triangulasi, yaitu menggunakan berbagai teknik pengumpulan data secara gabungan / simultan. Analisis data yang bersifat induktif berdasarkan fakta-fakta yang ditemukan di lapangan dan kemudian dikontruksikan menjadi hipotesis atau teori.

Dalam penelitian ini peneliti dapat mengamati secara mendalam dan langsung bagaimana cara penggunaan antibiotik yang dilakukan pasien, kemuadian peneliti dapat berinteraksi langsung kepada pasien sehingga data yang diperoleh dari informasi yang didapat dari pasien lebih nyata dan akurat tentang bagaimana cara penggunaan antibiotik yang biasa dilakukan oleh pasien yang sebelumnya mereka peroleh dari puskesmas.

Berdasarka hasil penelitian bahwa antibiotik yang paling banyak digunakan adalah Amoxicilin 500 mg dengan aturan pakai 3 kali sehari dan cefadroxil $500 \mathrm{mg}$ dengan aturan pakai 2 kali sehari. Kemudian, dari hasil pengamatan dan wawancara melalui kunjungan ke rumah pasien secara langsung, peneliti dapat mengetahui bahwa 10 pasien yang telah diwawancarai setelah berobat ke pustu kebanyakan dari mereka diberikan obat antibiotik yaitu Amoxicilin.

Dari 10 pasien yang diwawancarai 4 diantaranya mengetahui tentang antibiotik 
yang digunakannya. Dalam menperoleh antibiotik dipustu semua pasien mendapatkan informasi yang lengkap tentang penggunaan antibiotik meliputi frekuensi penggunaan obat antibiotik, waktu penggunaan antibiotik, lama penggunaan antibiotik dan keterangan dihabiskan misalnya frekuensi penggunaan antibiotik aturan pakai 3 kali sehari I kali, kemudian waktu penggunaan obat antibiotik berapa kali obat digunakan dalam sehari, apakah di waktu pagi, siang, sore, atau malam dan juga sesudah atau sebelum makan. Lama penggunaan obat, apakah selama keluhan masih ada atau harus dihabiskan meskipun sudah terasa sembuh. Keterangan dihabiskan, obat antibiotik harus dihabiskan untuk mencegah timbulnya resistensi. Petunjuk pemakaian obat oral ( pemberian obat melalui mulut) adalah cara yang paling lazim, karena sangat praktis, mudah dan aman.

\section{KESIMPULAN}

Dari hasil penelitian yang telah dilakukan dapat ditarik kesimpulan bahwa cara penggunaan antibiotik pada pasien yang berobat di puskesmas pembantu desa basawang kecamatan teluk sampit yang meliputi frekuensi, waktu penggunan, lama penggunaan obat antibiotik dan keterangan dihabiskan sudah cukup sesuai dengan yang diberikan oleh tenaga kesehatan di puskesmas pembantu desa basawang.

\section{DAFTAR PUSTAKA}

1. Hasnal, Laili Y., Yanwirasti., dan Irawati. 2015, Hubungan Tingkat Pengetahuan dan Sikap dengan Penggunaan Antibiotik Tanpa Resep Dokter "Padang. Fakultas Kedokteran, Universitas Andalas Padang, Jurnal Kesehatan Andalas No.4 Volume 1,2015

2. Nita, Ayu T., Miranti, Kania D., dan Susanti Yulia. 2014, Hubungan Tingkat Pendidikan dan Status Ekonomi Terhadap Tingkat Pengetahuan Antibiotik, "Bandung: Prosiding Penelitian Sivitas Akademika UNISBA (Kesehatan). Pendidikan Dokter, Fakultas Kedokteran, Universitas Islam.

3. Notoatmodjo, Soekidjo. 2010, Metodologi Penelitian Kesehatan. Jakarta: Rineka Cipta.

4. Tan Hoan Tjay dan K, Raharja, 2007, Obat-obat Penting, Jilid VI; Cetakan pertama, Jakarta, Elex Media Komputindo Kelompok Gramedia.

5. Sugiyono. 2015. Metode Penelitian Administrasi Dengan Metode $R \& D$. Bandung: CV Alvabeta.

6. WHO Global Strategy for Containment o Antimicrobial Resistance, 22-23, WHO, Geneva. Dalam Zakia, Sufiantinur. 2013. "Gambaran Pengetahuan Antibiotik Masyarakat Di Kelurahan Panarung dan Pahandut Seberang, Kecamatan Pahandut, Palangka Raya " Yogyakarta: Skripsi Fakultas Farmasi Universitas Gadjah Mada 